\title{
Re-viewing raphides: Issues with the identification and interpretation of calcium oxalate crystals in microfossil assemblages
}

\author{
Alison Crowther
}

\author{
School of Social Science \\ The University of Queensland \\ St Lucia QId 4072, Australia \\ alison.crowther@gmail.com
}

\begin{abstract}
Needle-shaped calcium oxalate crystals called raphides are increasingly being identified in microfossil assemblages from archaeological sites, including in sediments and as residues on artefacts. This paper reviews issues associated with the identification and interpretation of raphides in the archaeological record of the Pacific. It is argued that, with a better understanding of the occurrence, distribution, and morphological variability of raphides across higher plant families, more accurate and meaningful interpretations can be made of these archaeological microfossils. Problems with differentiating raphides from naturally occurring calcite crystals of similar morphology and optical properties are briefly raised and illustrated using the analysis of microscopic residues on Lapita pottery from sites in Melanesia.
\end{abstract}

Keywords: Calcium oxalate crystals, raphides, microfossils, residue analysis, Araceae, Pacific

\section{Introduction}

The analysis of plant microfossils such as starch, phytoliths and pollen is gaining momentum in Pacific archaeology. Such studies have made important contributions to palaeoenvironmental reconstructions and our understanding of past human-plant interactions. This paper focuses on the analysis of calcium oxalate crystals, which have been reported in a number of archaeological microfossil assemblages worldwide, including as residues on stone tools (e.g. Bernard-Shaw 1984 cited in Bernard-Shaw 1990:193; Fullagar 1993b; Fullagar et al. 2006; Hardy 2004; Hardy et al. 2001; Loy et al. 1992; Shafer and Holloway 1979; Sobolik 1994) and pottery surfaces (Crowther 2005; Horrocks and Bedford 2005), in coprolites (Danielson and Reinhard 1998; Jones and Bryant 1992; Reinhard and Danielson 2005), and in sediments 
from hearths and roasting pits (Bernard-Shaw 1990; Koumouzelis et al. 2001), burials (Lalueza Fox et al.1996) and wetland ditch systems (Horrocks and Barber 2005). These crystals, which are sometimes referred to in the literature as calcium oxalate phytoliths, are the most commonly formed biomineral in higher plants (Webb et al. 1995).

Calcium oxalate crystals are generally considered to be of lesser archaeological importance than other microfossils owing to their more restricted range of forms, which are rarely diagnostic to family (Lalueza Fox et al. 1996:106; cf. Jones and Bryant 1992). In the Pacific region, however, needle-shaped calcium oxalate crystals known as raphides have been drawn upon as an important indicator of aroids (a group that includes the Pacific food staples Colocasia esculenta [taro], Alocasia macrorrhiza, and Cyrtosperma chamissonis [giant swamp taro]) in microfossil assemblages. The aroids are a subgroup of the Araceae, which is a family of mainly herbaceous plants that are known to produce raphides in abundance. Raphides have long been associated with the acridity of the aroids, meaning that when eaten raw they cause swelling of the lips, mouth and throat. It is now understood, however, that raphides only act as a conduit for the injection of an associated chemical irritant into the skin. Detoxification via cooking, pounding or leaching neutralises the chemical, hence making the aroids edible, but does not destroy or degrade the raphides (Bradbury and Nixon 1998; Johns and Kubo 1988; Paull et al. 1999; Sakai 1979). In the Pacific region, raphides alongside other microfossil types have been drawn on as evidence for Pleistocene processing of starchy plants (Loy et al. 1992), the development of agriculture (Denham et al. 2003; Fullagar et al. 2006), the timing of plant introductions, and the integration of horticulture into prehistoric economies (Horrocks and Bedford 2005).

Given the increasing incorporation of raphides into microfossil studies, this paper aims to review issues associated with their identification and interpretation. First, it examines how microfossil researchers in the past have interpreted raphides in archaeological assemblages from the Pacific, and how these interpretations might be improved with a better understanding of both the widespread occurrence of raphides in higher plant families, and higher resolution analyses of raphides using scanning electron microscopy (SEM). Second, it examines identification problems with raphides, in particular the possibility that naturally occurring calcite crystals of similar morphologies and optical properties might be misidentified as raphides in microfossil assemblages. Both these issues are non-trivial considering the importance of raphide-bearing plants in the Pacific economy, and the growing use of these microfossils to identify such plants in the archaeological record.

\section{Occurrence of calcium oxalate crystals in higher plants}

Calcium oxalate crystals occur in more than 215 higher plant families, as well as the algae, lichen and fungi, in the form of whewellite $\left(\mathrm{CaC}_{2} \mathrm{O}_{4} \cdot \mathrm{H}_{2} \mathrm{O}\right)$ or weddelite $\left(\mathrm{CaC}_{2} \mathrm{O}_{4} \cdot 2 \mathrm{H}_{2} \mathrm{O}\right)$ (Bouropoulos et al. 2001; Horner and Wagner 1995:54). They can form in any organ or tissue within plants, including in stems, leaves, roots, tubers, and seeds, and have a variety of functions including calcium storage, defence and providing structural strength (Franceschi and Horner 1980; Franceschi and Nakata 2005; Nakata 2003). Unlike phytoliths, which vary considerably in size and shape across families, calcium oxalate crystals are generally restricted to five basic morphological types: needle-shaped raphides, rectangular or pencilshaped styolids, mace-head-shaped aggregates called druses, block-shaped aggregates called crystal sand, and variously shaped prisms (Horner and Wagner 1995) (Figure 1). Given that the size and appearance of these crystals can differ within and between families, and that these morphological characteristics are probably under genetic control (e.g. a plant species always produces the same form of crystal in the same tissue [Bouropoulos et al. 2001]), calcium oxalate crystals may have taxonomic potential for both botanists and archaeologists (Horner and Wagner 1995). 

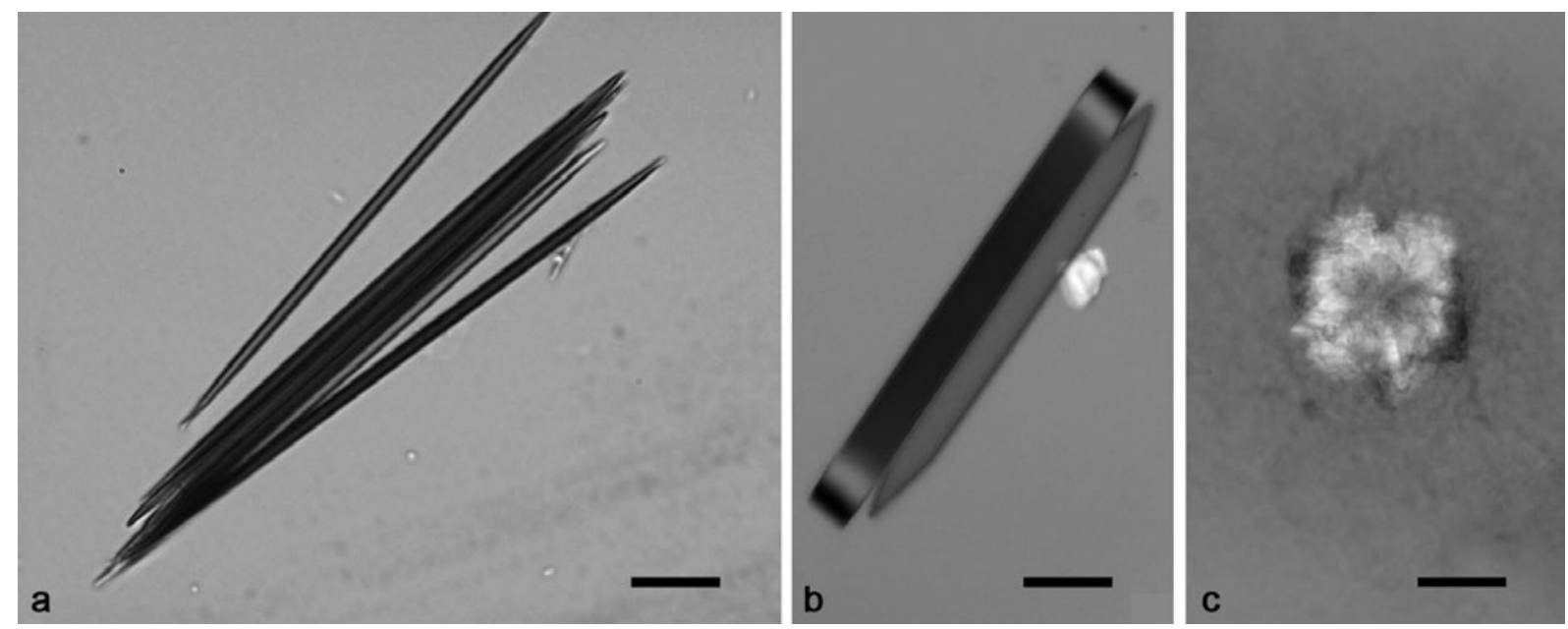

Figure 1. Examples of calcium oxalate crystal forms most commonly found in monocotyledons:

(a) needle-shape raphides, (Pandanus sp. leaf; brightfield transmitted light, scale bar equals $10 \mu \mathrm{m}$ );

(b) rectangular and pencil-shaped (pointed) styloids (Cordyline sp. leaf; brightfield transmitted light, scale bar equals $20 \mu \mathrm{m}$ ); and

(c) druse (Colocasia esculenta corm; brightfield transmitted light, scale bar equals $20 \mu \mathrm{m}$ ).

Raphides most commonly occur in bundles of tens to hundreds of crystals in specialised cells called idioblasts (Figure 2). Although less common, they are also known to form in extracellular bundles (e.g. Barabé et al. 2004) and there has been one report of raphides forming within starch granules (Okoli and Green 1987). Idioblast cells are structurally modified to accommodate crystals and are therefore markedly different in form, structure, and contents from other cells in the same tissue (Gallaher 1975:320; Sunell and Healey 1981:235). A variety of idioblast cell forms have been identified (see Keating 2004), which can be grouped broadly into those having defensive or non-defensive functions (Sunell and Healey 1985). The latter form crystals in relatively loose arrangement compared to defensive cells, which are usually smaller in size and suspended in the intercellular airspaces from where they are easily dislodged (Sunell and Healey 1985). When a defensive idioblast is disrupted, the tightly packed raphides are ejected through thin-walled papillae at its ends (Sunell and Healey 1981:236), a feature likened to an 'automatic microscopic blowgun' (Middendorf 1983:9) (Figure 3). This mechanism probably developed as a defence against herbivores.

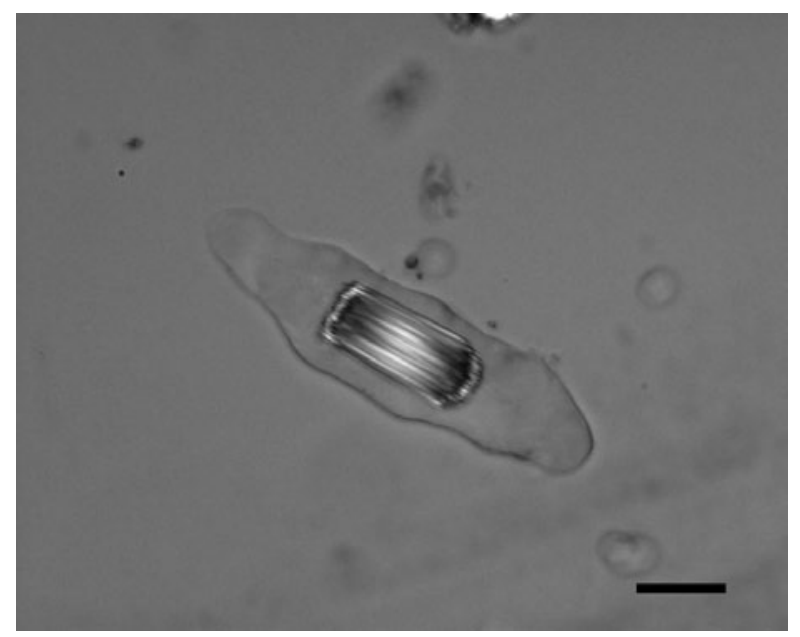

Figure 2. Bundle of sp. (tuber) raphides in idioblast cell (part-polarised brightfield transmitted light, scale bar equals $100 \mu \mathrm{m})$.

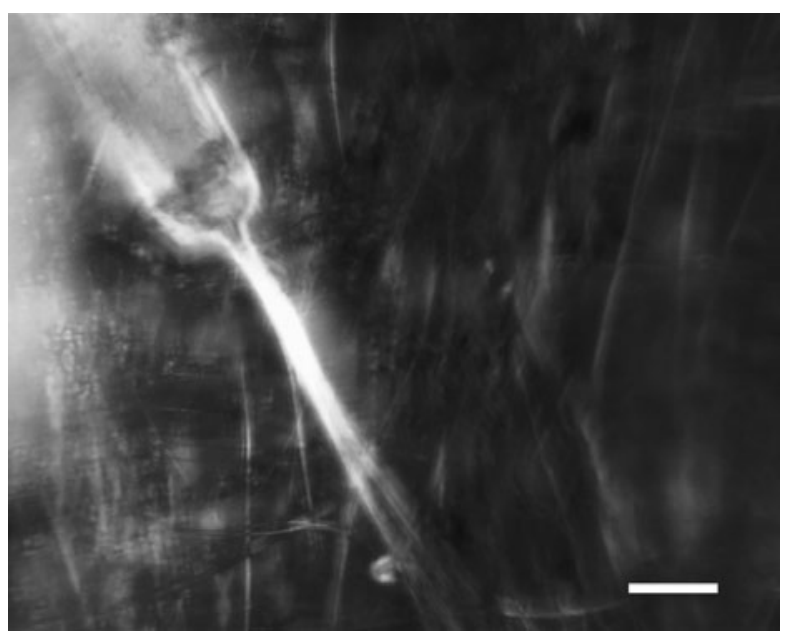

Figure 3. Spindle-shaped defensive idioblast cell from Colocasia esculenta corm. Raphides are partially ejected through the papilla at its end (cross-polarised brightfield transmitted light, scale bar equals $20 \mu \mathrm{m})$. 
Raphides and other crystals of calcium oxalate are relatively stable minerals. They are only slightly water soluble (Graustein et al. 1977:199; Webb 1999:752), and are insoluble in alkalis (i.e. bases; high $\mathrm{pH}$ conditions) and organic acids (e.g. carboxylic acids such as acetic acid) (Gallaher 1975:315). They are heat resistant and can therefore survive cooking. As Monje and Baran (2002:711) summarise, 'the oxalates have the particular advantage to be very resistant water-insoluble plant products and, thus, they could be found where other plant residues are no longer evident'. Raphides are not entirely indestructible, however, as they are susceptible to damage from mechanical action as well as dissolution in acidic environments (Mulholland and Rapp 1992:4).

\section{Background to the identification and interpretation of raphides in the Pacific archaeological record}

The presence and potential importance of raphides in the archaeological record of the Pacific region was first highlighted by Loy, Spriggs and Wickler (1992; see also Loy 1994), who found these crystals in association with starch residues on the edges of stone tools as old as 28,000 years from the Solomon Islands. Following analysis of limited modern reference material from aroids, yams, and other economic species from the region, Loy and his colleagues made two key findings regarding raphide identification and interpretation. First, the abundance of raphides in aroids and near absence from other plants analysed in their study could broadly support the identification of starch residues from aroids when the two microfossil types are associated in use-residues. Notably, Loy et al. (1992) relied on starch granule size and shape as a more significant taxonomic indicator than the presence of raphides. Second, the size and morphology of raphides from the aroids was sufficiently varied to potentially differentiate them at species level, although these differences were only briefly described (Loy et al. 1992:900, 905-906). Loy et al.'s (1992) study has formed the basis of raphide identifications in Pacific microfossil studies, but their findings have been subject to little further review.

Raphides are known to occur in at least 49 monocotyledon and 27 dicotyledon families worldwide (Dahlgren and Clifford 1982:92-93; McNair 1932; Metcalfe and Chalk 1979:217; Prychid and Rudall 1999), including many that are commonly associated with archaeological sites in the Pacific region or had probable prehistoric economic importance. These include palms (Arecaceae) (Tomlinson 1971), pandanus (Pandanaceae), cordyline (Laxmanniaceae), bananas (Musaceae) (Osuji and Ndukuwu 2005; Osuji et al. 2000) and yams (Dioscoreaceae) (Ayensu 1972; see also Al-Rais et al. 1971; Okoli and Green 1987). For the last family, it is reported that raphides occur in at least 51 species worldwide (Ayensu 1972), even though Loy et al. (1992) only observed them in one of seven species (Dioscorea esculenta) in their study, possibly as a result of sampling error (cf. Loy et al. 1992:910). Hence, the presence of raphides in microfossil assemblages from the Pacific region could potentially represent a number of economically important taxa. Of the published studies in which raphides have been identified in microfossil assemblages from this region (see Table 1), all have identified the observed crystals to the Araceae, although Fullagar (1993a:335, 1993b:25) acknowledges the possibility that raphides on a stemmed tool from West New Britain could also be from yam. It is therefore important to examine and evaluate the reasoning underlying these identifications, and identify avenues by which they can be refined and strengthened.

The Araceae are known to produce abundant quantities of raphides in all or most organs - for example, a single Colocasia esculenta corm may contain up to 120000 calcium oxalate raphides and druses per cubic centimetre (Sunell and Healey 1979:1031; see also Bradbury and Nixon 1998; Genua and Hillson 1985; Keating 2004; Sakai 1979). This abundance is one of the most commonly used characteristics to distinguish Araceae raphides in microfossil studies (Crowther 2005; Horrocks and Bedford 2005; Horrocks and Weisler 2006; Loy et al. 1992), even though quantitative comparative analyses of raphide concentrations in economic plants from the Pacific have yet to be undertaken. It is suggested, for 


\begin{tabular}{|c|c|c|c|}
\hline Location & Sample type & Taxonomic identification of raphides & Reference \\
\hline $\begin{array}{l}\text { Kilu Cave, } \\
\text { Buka, Solomon } \\
\text { Islands }\end{array}$ & Stone tools & $\begin{array}{l}\text { Araceae (Alocasia macrorrhiza and } \\
\text { Colocasia esculenta - direct } \\
\text { association with starch) }\end{array}$ & Loy et al. 1992 \\
\hline $\begin{array}{l}\text { Bitokara, West } \\
\text { New Britain, } \\
\text { PNG }\end{array}$ & Stone tools & $\begin{array}{l}\text { Araceae and/or Dioscoraceae } \\
\text { (probably C. esculenta and/or } \\
\text { Dioscorea sp. - direct association } \\
\text { with starch) }\end{array}$ & $\begin{array}{l}\text { Fullagar 1993b } \\
\text { (see also Fullagar } \\
\text { 1993a) }\end{array}$ \\
\hline Anir, PNG & $\begin{array}{l}\text { Sediments \& } \\
\text { potsherds }\end{array}$ & $\begin{array}{l}\text { Araceae (probably Colocasia esculenta- } \\
\text { possibly associated with starch) }\end{array}$ & Crowther 2005 \\
\hline New Zealand & Sediments & $\begin{array}{l}\text { Araceae (C. esculenta - indirect } \\
\text { association with starch in } 2 \text { of } 6 \text { samples) }\end{array}$ & $\begin{array}{l}\text { Horrocks and } \\
\text { Barber } 2005\end{array}$ \\
\hline Uripiv, Vanuatu & $\begin{array}{l}\text { Sediments \& } \\
\text { potsherds }\end{array}$ & $\begin{array}{l}\text { Araceae (non-Colocasia - indirect } \\
\text { association with starch) }\end{array}$ & $\begin{array}{l}\text { Horrocks and } \\
\text { Bedford } 2005\end{array}$ \\
\hline $\begin{array}{l}\text { Henderson and } \\
\text { Marshall Islands. }\end{array}$ & Sediments & $\begin{array}{l}\text { Araceae (non-Colocasia - indirect } \\
\text { association with starch) }\end{array}$ & $\begin{array}{l}\text { Horrocks and } \\
\text { Weisler } 2006\end{array}$ \\
\hline $\begin{array}{l}\text { Kuk Swamp, } \\
\text { PNG }\end{array}$ & Stone tools & $\begin{array}{l}\text { Araceae (Colocasia esculenta - } \\
\text { direct association with starch) }\end{array}$ & $\begin{array}{l}\text { Fullagar et al. } 2006 \\
\text { (see also Denham } \\
\text { et al. 2003) }\end{array}$ \\
\hline
\end{tabular}

Table 1. Summary of studies that identify calcium oxalate raphides in archaeological sites in the Pacific region.

example, that raphides are also both abundant and widespread in the palms (Tomlinson 1961), suggesting that this feature is not unique to the Araceae. Quantitative analyses also need to account for the possibility that one idioblast cell alone can contain hundreds of raphides that, in a single event, could be deposited in the archaeological record in a concentrated mass. Cultural processes potentially leading to the build up of raphides in sediments, as well as taphonomic processes that might differentially affect archaeological raphide assemblages and subsequently their quantitative analysis, must also be assessed. Within our current state of knowledge, it can be argued that the quantity of raphides present in a microfossil assemblage is essentially meaningless in relation to their taxonomic identification.

More reliable raphide identifications may be possible in cases where they co-occur with other taxonomically distinctive microfossils, such as starch granules or phytoliths. The strength of such identifications, however, relies in part on their degree of association in the archaeological record. For example, it can be argued that raphides and starch granules observed in direct association on the used edge of a stone tool are likely to be related and therefore together they may enable stronger taxonomic identifications of the residue, based on a wider range of attributes (Fullagar 1993b; Fullagar et al. 2006; Loy et al. 1992). Where similar identifications have been made of raphides associated with starch in sediments, however, the relationship between the two is arguably relatively indirect given that, when analysed for pollen and phytoliths, the same samples are found to contain residues of a number of plant taxa (e.g. Horrocks and Barber 2005; Horrocks and Bedford 2005). As it cannot be assumed that the microfossils in sediment samples are taxonomically related, the evidence for each microfossil type must be independently as strong as possible. 
The final line of reasoning by which analysts have taxonomically identified raphides in Pacific microfossil assemblages has been on the basis of morphometric characteristics, following Loy et al.'s (1992) descriptions of aroid raphides. These attributes, however, have yet to be evaluated based on more comprehensive reference collection analyses and have been only minimally incorporated into archaeological raphide analyses since. Fullagar et al. (2006), for example, mention the square crosssection of a raphide found in association with Colocasia esculenta-type starch granules on a stone tool from Kuk Swamp in the central highlands of Papua New Guinea. Other studies simply describe microfossil raphides as typical of or similar to those from the aroids without presenting detailed morphometric data of both the archaeological samples and modern reference specimens (including nonAraceae) to lend weight to their identifications (Crowther 2005; Fullagar 1993b:25; Horrocks and Barber 2005; Horrocks and Bedford 2005). It is insufficient for taxonomic purposes to note that a crystal or broken crystal segment fits within the size and shape range of a particular genus or family without discussing other possible matches. Combining this point with that concerning microfossil co-occurrence, cases where raphides alone have been used to identify taxa present in sediments, even to species level (e.g. Horrocks and Barber 2005:Figure 6), are clearly problematic. As outlined below, the taxonomic significance of raphide morphology may have greater value than realised in these studies, particularly for the Araceae, and may reduce reliance on the potentially ambiguous criteria discussed above.

\section{Micromorphological identification of raphides using SEM}

Anatomical and tissue culture studies indicate that raphide morphology and formation in specific locations within a plant are genetically controlled (Horner and Wagner 1995). Key attributes for differentiating raphides include size, cross-section and termination morphology, all of which appear to vary to differing degrees depending on taxa of origin. Fragmentation and degradation of archaeological raphides, however, limits the potential for taxonomic differentiation using some of these attributes (see Crowther 2005:64-65; Horrocks and Bedford 2005:70-71). For example, morphologically distinctive features such as terminations may not be present and size can be difficult to estimate from broken crystals. While cross-section has been noted in some studies using light microscopy (e.g. Fullagar et al. 2006:605; Loy et al. 1992), personal experience shows that unambiguous analysis of raphide sectional shape is often beyond the resolution limits of the light microscope. Scanning electron microscopic analysis of raphide cross-sectional shape and terminations (where present), however, may have greater taxonomic potential.

SEM studies of raphides from a number of higher plants have described four general morphological types, referred to here as Types I-IV (Figure 4) (Cody and Horner 1983:328).

Type I is the most common raphide form and consists of four-sided single crystals that have two symmetrical pointed ends (Figure 5).

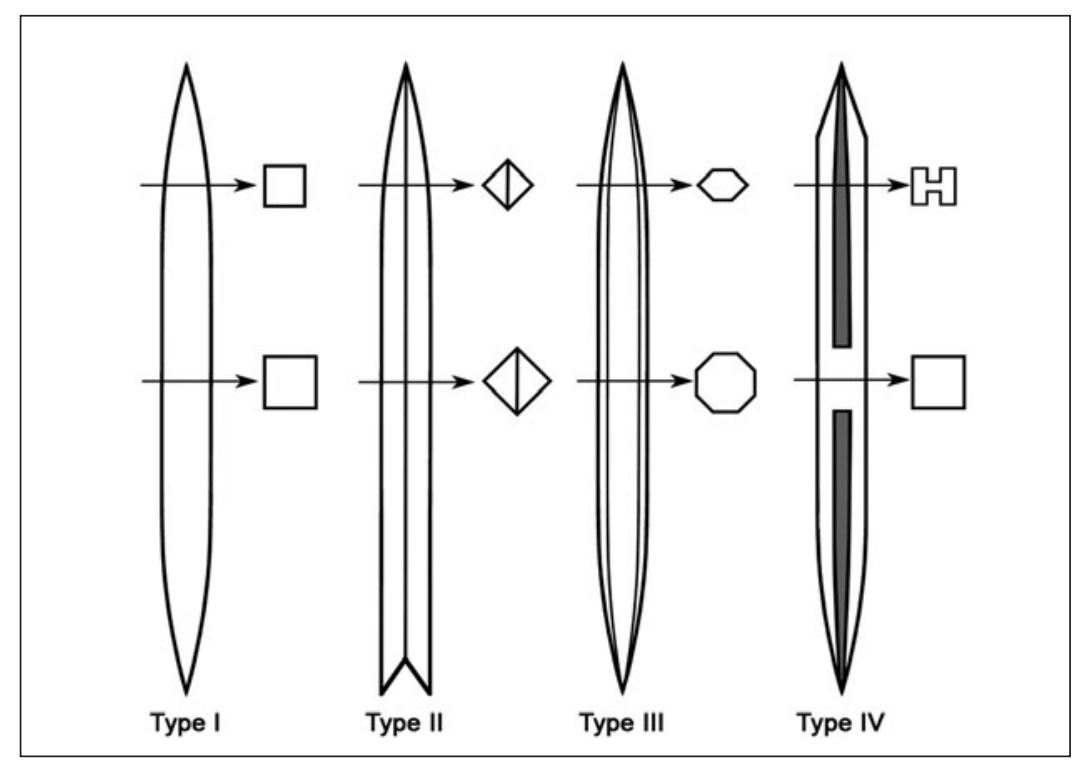

Figure 4. Diagram showing the four basic types of raphide cross-sections. End forms are described in text (redrawn from Horner and Wagner 1995: 58). 

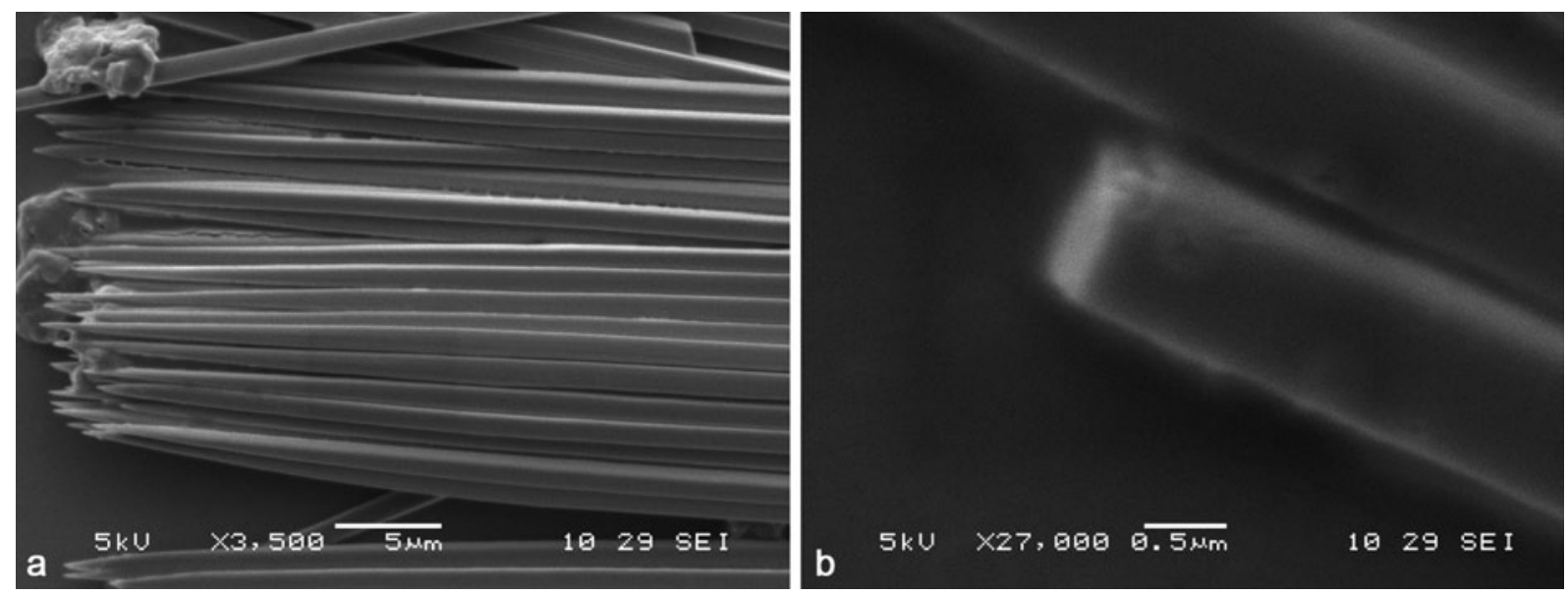

Figure 5. SEM micrographs of Pandanus Sp. (leaf) raphides showing (a) part of bundle of four-sided crystals, and (b) broken raphide with square cross-section.

Type II raphides, which are also four-sided, have one pointed and one bidentate or forked end (Prychid and Rudall 1999:726). This type of raphide has so far only been recorded in a few families such as the Vitaceae (Figure 6) (Cody and Horner 1983; Webb 1999). The bidentate end is formed by crystal twinning (Arnott and Webb 2000:133).
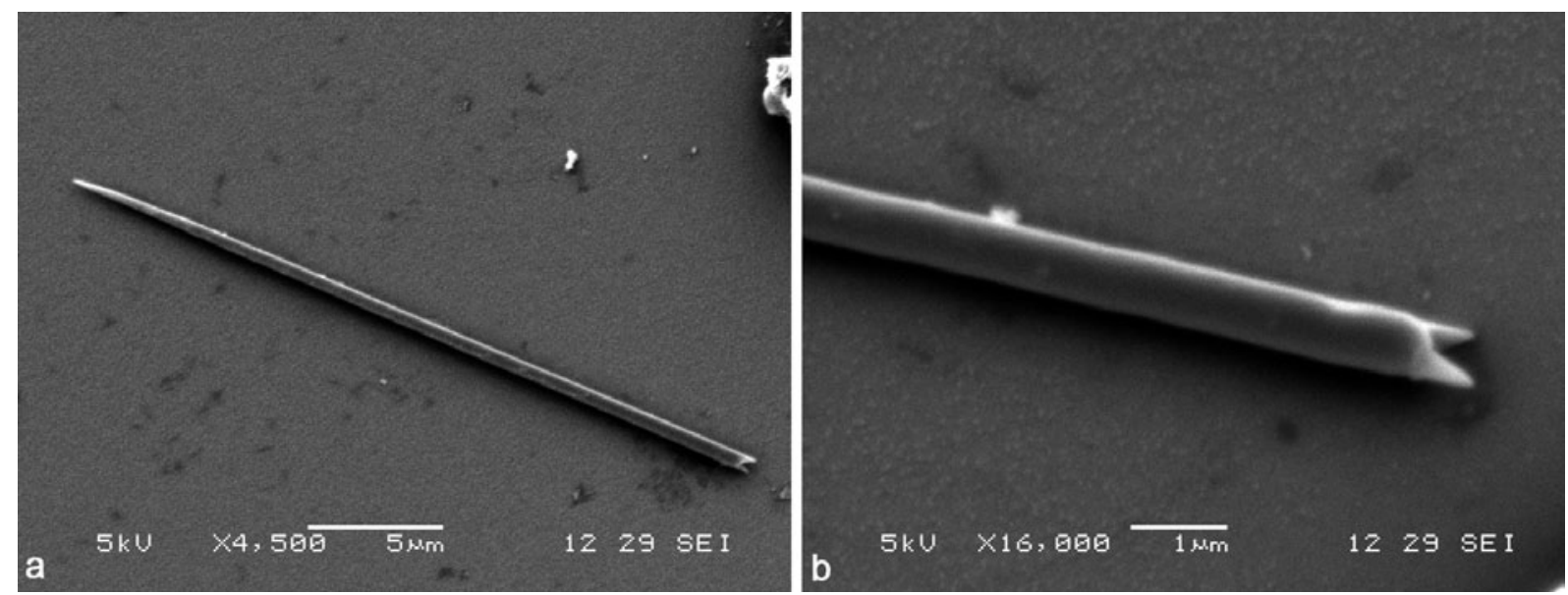

Figure 6. (a) SEM micrograph of Type II raphide from Vitis sp. (stem). (b) Detail of bidentate end.

The third form (Type III) are crystals with six to eight sides and symmetrical pointed ends. This raphide type is known to occur in the Agavaceae (Wattendorf 1976), Typhaceae (Horner et al. 1981), and Dioscoreaceae (Figure 7).

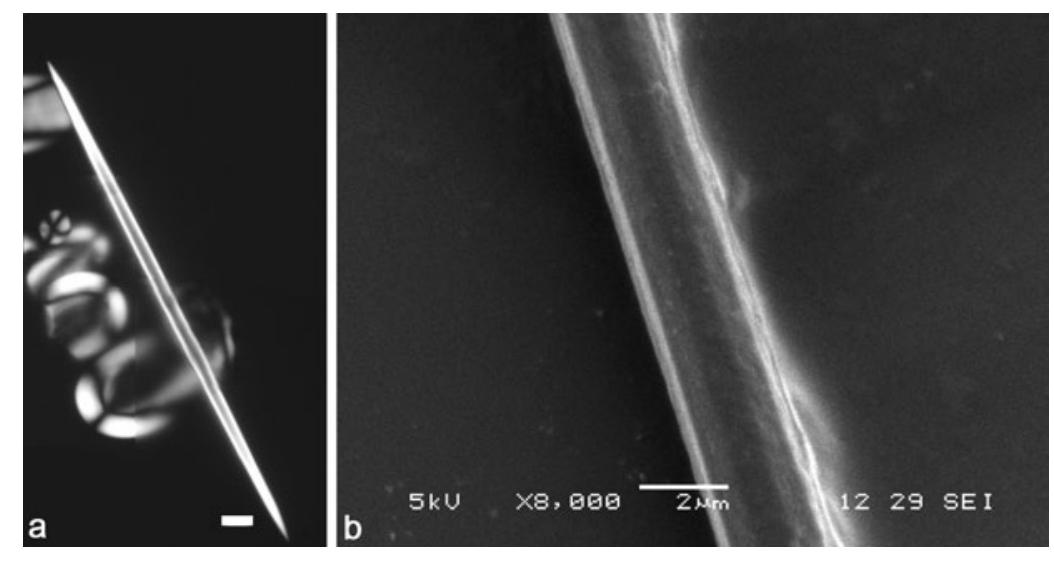

Figure 7. (a) Type III raphide from Dioscorea alata (tuber) (brightfield transmitted light, composite photograph, scale bar equals $10 \mu \mathrm{m}$ ) and (b) SEM micrograph of mid-section of Dioscorea sp. (tuber) raphide showing faceted faces. 
Crystals of this morphological type are sometimes described as appearing elliptical or circular in crosssection as viewed under a light microscope (Loy et al. 1992:900; Prychid and Rudall 1999:726).

The fourth raphide form (Type IV) comprises twinned crystals with H-shaped cross-sections and asymmetrical ends (one wedge-shaped and the other sharply pointed) (Figure 8a) (Bradbury and Nixon 1998; Kostman and Franceschi 2000). A medial groove along two of the crystal's opposite faces gives this type its overall $\mathrm{H}$-shaped cross-section, although the solid mid-point of the raphide is 4-sided and sometimes visible under a polarised light microscope (Figure 8b-c). Type IV raphides also develop barbs on their pointed ends as they mature (Bradbury and Nixon 1998:614; Prychid and Rudall 1999:726; Sakai et al. 1972). Significantly for microfossil researchers, the H-shaped form is thought to be unique to raphides from the Araceae and therefore offers great potential for taxonomic identification (Prychid and Rudall 1999). Barbs, on the other hand, have been noted in other taxa (Cody and Horner 1983:319).

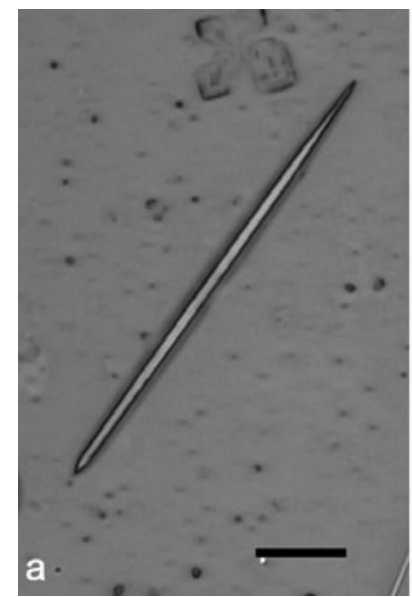

Figure 8. Type IV raphides from
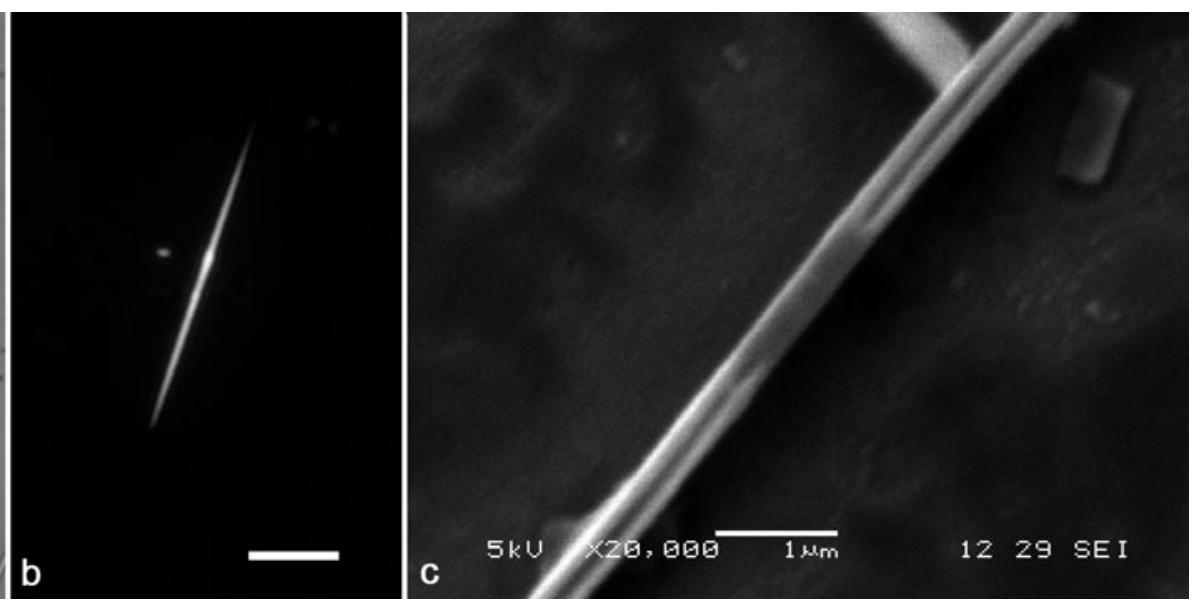

(leaf) showing (a) asymmetrical end terminations (brightfield incident light, scale bar equals $10 \mu \mathrm{m})$, (b) thickened central region as visible under cross-polarised light (brightfield transmitted light, scale bar equals $20 \mu \mathrm{m})$, and (c) groove and thickened region as observed under SEM.

A final point on using morphometric characteristics to identify calcium oxalate crystals relates to size. The relationship between crystal size and taxa of origin is complicated by the fact that size can vary within a species, depending partly on intrinsic (i.e. genetic) variables, such as the function of the cell in which the crystal is formed, and partly on environmental factors including the amount of calcium available during crystal formation (see Franceschi and Nakata 2005). The degree of variation within species therefore needs to be assessed before size is accepted as a reliable indicator of taxa of origin.

Based on this review, it is likely that more reliable identifications of microfossil raphides may be achieved by incorporating higher resolution examinations of micro-morphological features into the analyses. This potential can only be fully assessed, however, through comprehensive reference collection analysis.

\section{Needle-fibre calcite: occurrence and implications for raphide analyses}

A second major issue in the analysis of raphides from Pacific microfossil assemblages relates to their differentiation from other crystals with similar morphologies and optical properties. All of the published cases that have identified raphides in the archaeological record have done so based solely on light microscopy. Using this technique, raphides have usually been identified as such by their acicular or needle-like morphology and optical properties such as pleochroism (colours that shift with varying degrees of polarisation) and birefringence (double refraction of light, which is evident by the bright 
appearance of the crystals in cross-polarised light) (see Figure 8b). During recent examination of Lapita potsherds from sites in Island Melanesia for surface residues, however, it was found that calcite crystals which had precipitated on the pottery can have forms and optical properties similar to calcium oxalate raphides (Figure 9). The archaeological crystals were identified as calcite, based on morphological descriptions provided by Phillips and Self (1987), Borsato et al. (2000) and Verrecchia and Verrecchia (1994), and chemical tests, as described below.
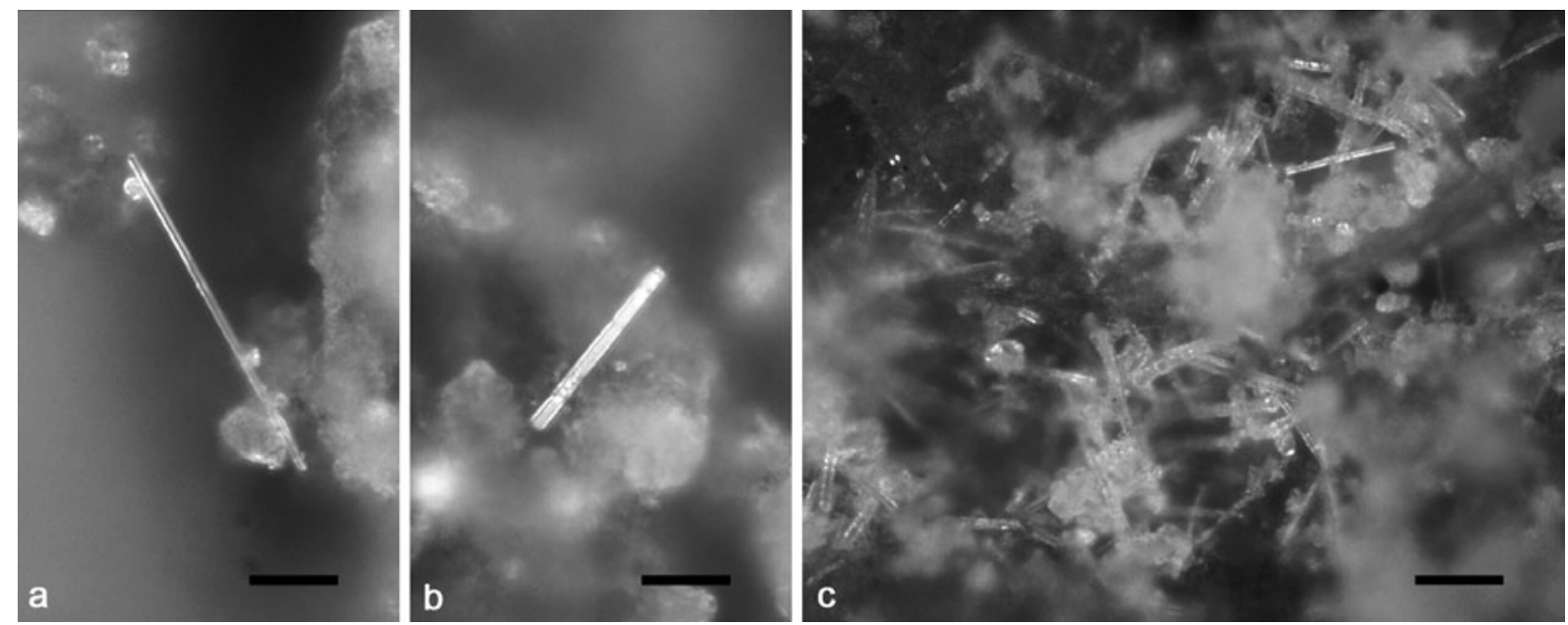

Figure 9. Examples of individual (a, b) and clustered (c) calcite crystals in situ on archaeological potsherds from the Mussau Islands, Papua New Guinea. Note the crystals' birefringence (bright appearance) and acicular forms, although ends are square rather than pointed. (All images: brightfield cross-polarised incident light, scale bar equals (a) $10 \mu \mathrm{m}$, (b) $10 \mu \mathrm{m}$, (c) $20 \mu \mathrm{m}$ ).

Needle-shaped calcite crystals are described in the literature as whisker crystals, acicular calcite, rock-milk, moonmilk, and lublinite, but most commonly as needle-fibre calcite. They form as smooth, single microrods that can fuse together in pairs of two, giving more complex morphologies with either H- or X-shaped cross-sections (Figure 10; cf. Type IV raphides) (Phillips and Self 1987; Verrecchia and Verrecchia 1994). Although some calcite crystals have small, tapered tips, most have blunt, square ends, while raphides generally have at least one sharp point. In highly fragmented archaeological assemblages, however, this distinction may not be as apparent (cf. Figure 11). Needle-fibre calcite can occur in bundles of sub-parallel rods, somewhat similar to the arrangement of raphides in an idioblast cell, or in randomly oriented meshes of individual crystals. Although the most common form of calcite crystals is straightsided, some can also be curved (Philips and Self 1987:435), a trait shared with some calcium oxalate raphides (see Loy et al. [1992:900] on 'whisker' raphides). In terms of size, both raphides and calcite crystals can have a similar range, with average widths between 1-2 $\mu \mathrm{m}$ and lengths up to c. 150-200 $\mu \mathrm{m}$, although some calcite crystals can be up to $1 \mathrm{~mm}$ in length (Bradbury and Nixon 1998; Phillips and Self 1987). The high degree of similarity in size, shape, optical properties and arrangement between needlefibre calcite and calcium oxalate raphides raises the possibility that the two could be confused when observed in microfossil assemblages.

Needle-fibre calcite precipitation can be related to either biological (e.g. produced as coatings on fungal mycelia) or inorganic processes (e.g. crystallisation from supersaturated calcium solutions) (Borsato et al. 2000; Verrecchia and Verrecchia 1994). They have been reported from a variety of environments exhibiting active pedogenic processes, including calcareous soils, calcrete, aeolianite, weathered limestone and limestone caves (Phillips and Self 1987:429). Finding an abundance of these crystals on the Lapita potsherds is not surprising, therefore, given that those examined are all from former beach-side locations. The occurrence of calcite crystals in the environments listed above will also 
have implications for studies of artefacts and sediments from limestone caves, upon which a great deal of Pacific archaeology relies. Not only might it be possible that naturally occurring needle-fibre calcite crystals be present in sites from these depositional environments, but if calcium oxalate raphides associated with plant-processing are also present, it may be difficult to differentiate them based on their morphological and optical properties alone.
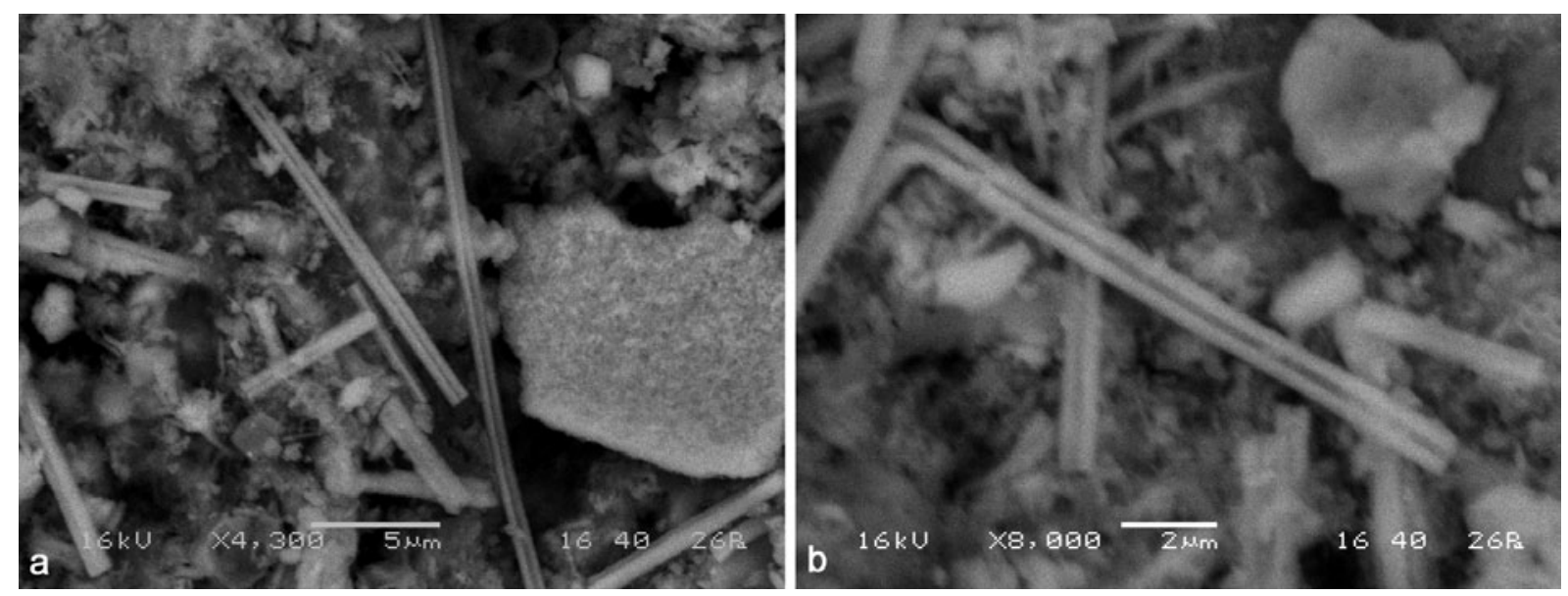

Figure 10. SEM micrographs of needle-fibre calcite crystals in situ on Lapita potsherds from the Mussau Islands, showing their grooved morphology similar to Type IV raphides from the Araceae.
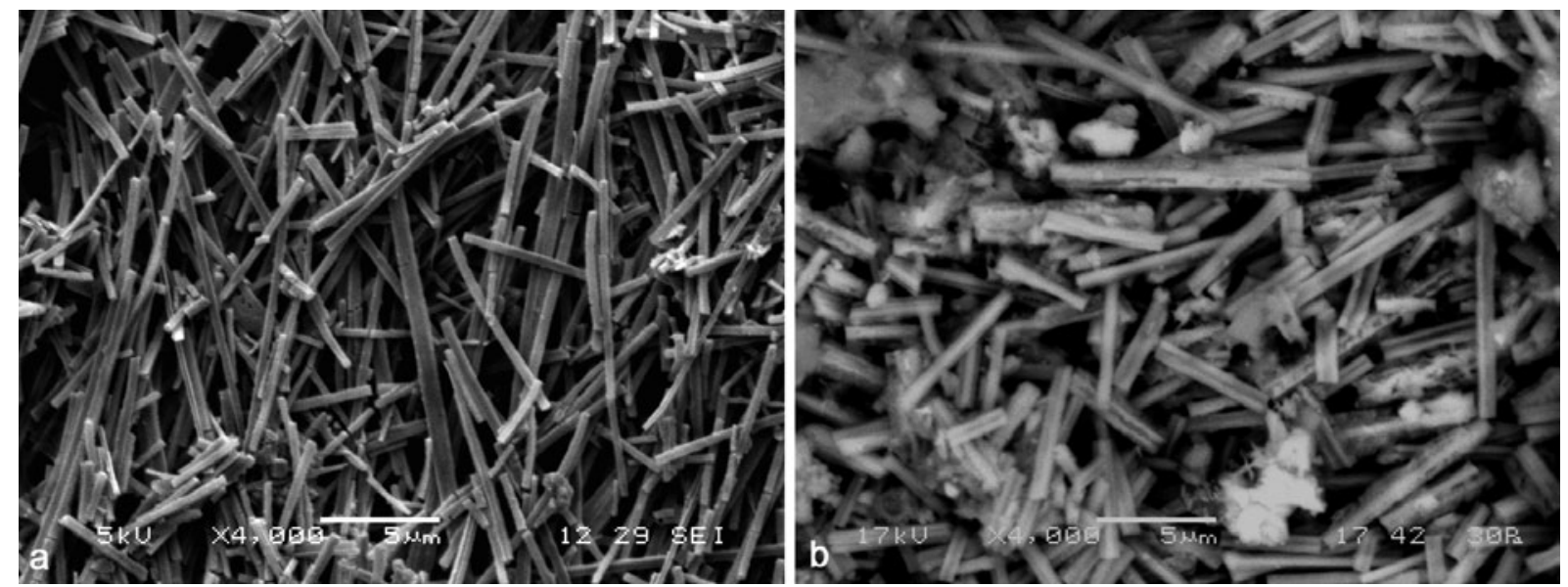

Figure 11. SEM micrographs at the same magnification comparing (a) a dense cluster of broken Alocasia macrorrhiza (leaf) raphides with (b) a concentration of in situ needle-fibre calcite crystals on a Lapita potsherd from the Reef Islands, southeast Solomon Islands. The fragmented raphides are virtually indistinguishable in size and form from the calcite crystals.

Where suspected raphides are found, a simple acid test could resolve their identification. For example, when a sample of crystals removed from one of the Lapita potsherds was treated with a small amount of weak $(5 \%)$ acetic acid, which is known to dissolve calcium carbonate but not calcium oxalate, all crystals rapidly dissolved. If the reaction is observed under the microscope, it may also be possible to see bubbles of carbon dioxide gas produced by the calcite as it dissolves, although in the experiments performed here the reaction occurred too quickly and vigorously to observe this phenomenon. By comparison, a sample of Alocasia macrorrhiza raphides treated with the same solution was not affected. This simple test supported an SEM analysis which suggested that the archaeological crystals were needle-fibre calcite rather than raphides. The use of histological stains that differentially stain calcium 
oxalate and calcium carbonate, such as silver nitrate $\left(\mathrm{AgNO}_{3}\right)$ (Pizzolato 1964; Yasue 1969) or Alizarin red S (Macnish et al. 2003; Proia and Brinn 1985), is another avenue currently under investigation. In any case, a combination of methods, including light microscopy, scanning electron microscopy and chemical tests, should be used to confirm the identification of raphides as such when found in archaeological sites, particularly from environments where needle-shaped crystals of other types might occur. Previous studies can also be strengthened by reanalysis of recovered assemblages using these techniques.

\section{Conclusion}

The major implication of this review is that microfossil and residue studies published to date, in which needle-like crystals have been identified through light microscopy as raphides from Pacific food plants, must treated with caution until more robust arguments for their identifications are presented. Many of the criteria upon which acicular crystals have been identified as raphides and then assigned a taxon of origin have yet to be shown to be reliable. Incorporation of higher resolution analyses of morphometric characteristics for taxonomic identification, and chemical tests, are necessary further steps for raphide analysis. This finding requires that a reexamination of previous and ongoing studies of raphides from Pacific archaeological sites be conducted before secure conclusions based on these crystals can be drawn. This is a non-trivial issue, as these conclusions influence our understanding of early horticulture and the timing of plant introductions in the region, especially concerning the use of important aroids such as taro.

With discussion of archaeological Pacific raphides increasing, it is timely to assess what is known about these crystals, how they are interpreted, and how they can be identified more accurately to taxa of origin. Previous archaeological studies of raphides have been restricted in the scope of their interpretation, which has focused on an association between raphides and the Araceae, as well as their identification, for which there has been a reliance on light microscopy rather than SEM, which is more suitable for examining taxonomically significant features. Before even attempting to answer questions about what type of raphides are involved, however, analysts need to establish that the crystals found in microfossil assemblages are in fact calcium oxalate raphides and not naturally occurring crystals of similar appearance. By resolving these issues, the analysis of calcium oxalate crystals, alongside starch granules, phytoliths, pollen and other microbotanical remains, can lead us to a firmer and more holistic understanding of plant use in Pacific prehistory.

\section{Acknowledgements}

Pottery samples were provided by Roger Green and Peter Sheppard (University of Auckland) and Patrick Kirch (University of California, Berkeley). This research was funded by the School of Social Science, The University of Queensland. Funding to attend the 6th Australasian Archaeometry Conference, 2005 was provided by The Department of Archaeology and Natural History, The Australian National University. I thank Michael Haslam, Ian Lilley and the reviewers for their valuable comments on earlier drafts of this paper, and Sandy Shearer (School of Social Science) and staff at the Centre for Microscopy and Microanalysis, The University of Queensland, for assistance with the SEM. CRC Press gave permission for the reproduction in modified form of Horner and Wagner's (1995:58) diagram as Figure 4. 


\section{References}

Al-Rais, A. H., A. Myers and L. Watson. 1971. The isolation and properties of oxalate crystals from plants. Annals of Botany 35:1213-1218.

Arnott, H. J. and M. A. Webb. 2000. Twinned raphides of calcium oxalate in grape (vitis): Implications for crystal stability and function. International Journal of Plant Science 161:133-142.

Ayensu, E. S. 1972. Anatomy of the Monocotyledons VI: Dioscoreales. Oxford: Clarendon Press.

Barabé, D., C. Lacroix, M. Chouteau and M. Gibernau. 2004. On the presence of extracellular calcium oxalate crystals on the inflorescences of Araceae. Botanical Journal of the Linnean Society 146:181-190.

Bernard-Shaw, M. 1990. Experimental agave fiber extraction. In M. Bernard-Shaw and F. Huntington (eds), Rincon Phase seasonal occupation of the Northern Tucson Basin, pp 181-196. Technical Report 90-2. Tucson: Centre for Desert Archaeology.

Borsato, A., S. Frisia, B. Jones, and K. Van Der Borg. 2000. Calcite moonmilk: Crystal morphology and environment of formation in caves in the Italian Alps. Journal of Sedimentary Research 70:1171-1182.

Bouropoulos, N., S. Weiner, and L. Addadi. 2001. Calcium oxalate crystals in tomato and tobacco plants: Morphology and in vitro interactions of crystal-associated macromolecules. Chemistry 7:1881-1888.

Bradbury, J. H. and R. W. Nixon. 1998. The acridity of raphides from the edible aroids. Journal of the Science of Food and Agriculture 76:608-616.

Cody, A. M. and H. T. Horner, Jr. 1983. Twin raphides in the Vitaceae and Araceae and a model for their growth. Botanical Gazette 144:318-330.

Crowther, A. 2005. Starch residues on undecorated Lapita pottery from Anir, New Ireland. Archaeology in Oceania 40:62-66.

Dahlgren, R. M. T. and H. T. Clifford. 1982. The Monocotyledons: A comparative study. London: Academic Press.

Danielson, D. R. and K. J. Reinhard. 1998. Human dental microwear caused by calcium oxalate phytoliths in prehistoric diet of the lower Pecos Region, Texas. American Journal of Physical Anthropology 107:297-304.

Denham, T. P., S. Haberle, C. J. Lentfer, R. L. K. Fullagar, J. Field, M. Therin, N. Porch and B. Winsborough. 2003. Origins of agriculture at Kuk Swamp in the Highlands of New Guinea. Science 301:189-193.

Franceschi, V. R. and H. T. Horner, Jr. 1980. Calcium oxalate crystals in plants. The Botanical Review 46:361-427.

Franceschi, V. R. and P. A. Nakata. 2005. Calcium oxalate in plants: Formation and function. Annual Review of Plant Biology 56:41-71.

Fullagar, R. L. K. 1993a. Flaked stone tools and plant food production: A preliminary report on obsidian tools from Talasea, West New Britain, PNG. In P. C. Anderson, S. Beyries, M. Otte and H. Plisson (eds), Traces et Fonction: Les Gestes Retrouvés, pp 331-337. Colloque International de Liége, Éditions ERAUL 50. Liége: ERAUL.

Fullagar, R. L. K. 1993b. Taphonomy and tool-use: A role for phytoliths in use-wear and residues analysis. In B. Fankhauser and R. Bird (eds), Archaeometry: Current Australasian research, pp 21-27. Canberra: Department of Prehistory, Research School of Pacific Studies, The Australian National University.

Fullagar, R. L. K., J. Field, T. P. Denham and C. J. Lentfer. 2006. Early and mid Holocene tool-use and processing of taro (Colocasia esulenta), yam (Dioscorea sp.) and other plants at Kuk Swamp in the highlands of Papua New Guinea. Journal of Archaeological Science 33:595-614.

Gallaher, R. N. 1975. The occurrence of calcium in plant tissue as crystals of calcium oxalate. Communications in Soil Science and Plant Analysis 6:315-330. 
Genua, J. M. and C. J. Hillson. 1985. The occurrence, type and location of calcium oxalate crystals in the leaves of fourteen species of Araceae. Annals of Botany 56:351-361.

Graustein, W. C., K. Cromack, Jr. and P. Sollins. 1977. Calcium oxalate: Occurrence in soils and effect on nutrient and geochemical cycles. Science 198:1252-1254.

Hardy, B. L. 2004. Neanderthal behaviour and stone tool function at the Middle Palaeolithic site of La Quina, France. Antiquity 78:547-565.

Hardy, B. L., M. Kay, A. E. Marks and K. Monigal. 2001. Stone tool function at the Paleolithic sites of Starosele and Buran Kaya III, Crimea: Behavioral implications. Proceedings of the National Academy of Sciences 98:10972-10977.

Horner, H. T., Jr, A. P. Kausch and B. L. Wagner. 1981. Growth and change in shape of raphide and druse calcium oxalate crystals as a function of intracellular development in Typha angustifolia L.

(Typhaceae) and Capsicum annuum L. (Solanaceae). Scanning Electron Microscopy 1981:251-62.

Horner, H. T., Jr. and B. L. Wagner. 1995. Calcium oxalate formation in higher plants. In S. R. Khan (ed.), Calcium Oxalate in Biological Systems, pp 53-72. Boca Raton: CRC Press.

Horrocks, M. and I. Barber. 2005. Microfossils of introduced starch cultigens from an early wetland ditch site in New Zealand. Archaeology in Oceania 40:106-114.

Horrocks, M. and S. Bedford. 2005. Microfossil analysis of Lapita deposits in Vanuatu reveal introduced Araceae. Archaeology in Oceania 40:67-74.

Horrocks, M. and M. I. Weisler. 2006. Analysis of plant microfossils in archaeological deposits from two remote archipelagos: The Marshall Islands, Eastern Micronesia, and the Pitcairn Group, Southeast Polynesia. Pacific Science 60:261-280.

Johns, T. and I. Kubo 1988. A survey of traditional methods employed for the detoxification of plant foods. Journal of Ethnobiology 8(1):81-129.

Jones, J. G. and V. M. Bryant. 1992. Phytolith taxonomy in selected species of Texas cacti. In G. Rapp, Jr. and S. C. Mulholland (eds), Phytolith systematics: Emerging issues, pp 215-238. New York: Plenum Press.

Keating, R. C. 2004. Systematic occurrence of raphide crystals in Araceae. Annals of the Missouri Botanical Garden 91:495-504.

Kostman, T. A. and V. R. Franceschi. 2000. Cell and calcium oxalate crystal growth is coordinated to achieve high-capacity calcium regulation in plants. Protoplasma 214:166-179.

Koumouzelis, M., B. Ginter and J. K. Kozlowski. 2001. The early Upper Palaeolithic in Greece: The excavations in Klisoura Cave. Journal of Archaeological Science 28:515-539.

Lalueza Fox, C., J. Juan and R. M. Albert. 1996. Phytolith analysis on dental calculus, enamel surface, and burial soil: Information about diet and paleoenvironment. American Journal of Physical Anthropology 101:101-113.

Loy, T. H. 1994. Methods in the analysis of starch residues on prehistoric stone tools. In J. G. Hather (ed.), Tropical archaeobotany: Applications and new developments, pp 86-114. London: Routledge.

Loy, T. H., M. Spriggs and S. Wickler. 1992. Direct evidence for human use of plants 28,000 years ago: Starch residues on stone artefacts from the northern Solomon Islands. Antiquity 66:898-912.

Macnish, A. J., D. E. Irving, D. C. Joyce, V. Vithanage, A. H. Wearing, R. I. Webb and R.L. Frost. 2003. Identification of intracellular calcium oxalate crystals in Chamelaucium uncinatum (Myrtaceae). Australian Journal of Botany 51:565-572.

McNair, J. B. 1932. The interrelation between substances in plants: Essential oils and resins, cyanogen and oxalate. American Journal of Botany 19:255-72.

Metcalfe, C. R. and L. Chalk. 1979. Anatomy of the Dicotyledons II: Wood structure and conclusion of the general introduction. Oxford: Clarendon Press.

Middendorf, E. A. 1983. The remarkable shooting idioblasts. Aroideana 6:9-11.

Monje, P. V. and E. J. Baran. 2002. Characterization of calcium oxalates generated as biominerals in cacti. Plant Physiology 128:707-713. 
Mulholland, S. C. and G. Rapp, Jr. 1992. Phytolith systematics: An introduction. In G. Rapp, Jr. and S. C. Mulholland (eds), Phytolith systematics: Emerging issues, pp 1-13. New York: Plenum Press.

Nakata, P. A. 2003. Advances in our understanding of calcium oxalate crystal formation and function in plants. Plant Science 164:901-909.

Okoli, B. E. and B. O. Green. 1987. Histochemical localization of calcium oxalate crystals in starch grains of yams (Dioscorea). Annals of Botany 60:491-394.

Osuji, J. O. and B. C. Ndukuwu. 2005. Probable functions and remobilisation of calcium oxalates in Musa L. African Journal of Biotechnology 4:1139-1141.

Osuji, J. O., B. E. Okoli and R. Ortiz. 2000. Taxonomic value of calcium oxalate crystals in Musa germplasm. Acta Horticulturae 540:137-146.

Paull, R. E., C.-S. Tang, K. Gross, and G. Uru. 1999. The nature of the taro acridity factor. Postharvest Biology and Technology 16:71-78.

Phillips, S. E. and P. G. Self. 1987. Morphology, crystallography and origin of needle-fibre calcite in Quaternary pedogenic calcretes of South Australia. Australia Journal of Soil Research 25:429-44.

Pizzolato, P. 1964. Histochemical recognition of calcium oxalate. Journal of Histochemistry and Cytochemistry 12:333-336.

Proia, A. D. and N. T. Brinn. 1985. Identification of calcium oxalate crystals using Alizarin red S stain. Archives of Pathology and Laboratory Medicine 109:186-189.

Prychid, C. J. and P. A. Rudall. 1999. Calcium oxalate crystals in monocotyledons: A review of their structure and systematics. Annals of Botany 84:725-739.

Reinhard, K. J. and D. R. Danielson. 2005. Pervasiveness of phytoliths in prehistoric southwestern diet and implications for regional and temporal trends for dental microwear. Journal of Archaeological Science 32:981-988.

Sakai, W. S. 1979. Aroid root crops, acridity and raphides. Tropical Foods 1:265-278.

Sakai, W. S., M. Hanson and R. C. Jones. 1972. Raphides with barbs and grooves in Xanthosoma sagittifolium (Araceae). Science 178:314-15.

Shafer, H. J. and R. G. Holloway. 1979. Organic residue analysis in determining stone tool function. In B. Hayden (ed.), Lithic Use-Wear Analysis, pp 385-399. New York: Academic Press.

Sobolik, K. D. 1994. Lithic organic residue analysis: An example from the southwestern Archaic. Journal of Field Archaeology 23:461-469.

Sunell, L.A. and P.L. Healey. 1979. Distribution of calcium oxalate crystal idioblasts in corms of taro (Colocasia esculenta). American Journal of Botany 66:1029-32.

Sunell, L. A. and P. L. Healey. 1981. Scanning electron microscopy and energy dispersive x-ray analysis of raphide crystal idioblasts in taro. Scanning Electron Microscopy 1981:235-244.

Sunell, L. A. and P. L. Healey. 1985. Distribution of calcium oxalate crystal idioblasts in leaves of taro (Colocasia esculenta). American Journal of Botany 72:1854-1860.

Tomlinson, P. B. 1961. Anatomy of the Monocotyledons II: Palmae. Oxford: Clarendon Press.

Verrecchia, E. P. and K. E. Verrecchia. 1994. Needle-fibre calcite: A critical review and a proposed classification. Journal of Sedimentary Research A64:650-664.

Wattendorff, J. 1976. A third type of raphide crystal in the plant kingdom: Six-sided raphides with laminated sheaths in Agave americana L. Planta 130:303-311.

Webb, M. A. 1999. Cell-mediated crystallization of calcium oxalate in plants. Plant Cell 11:751-761.

Webb, M. A., J. M. Cavaletto, N. C. Carpita, L. E. Lopez and H. J. Arnott. 1995. The intravacuolar organic matrix associated with calcium oxalate crystals in leaves of Vitis. The Plant Journal 7:633-648.

Yasue, T. 1969. Histochemical identification of calcium oxalate. Acta Histochemica et Cytochemica 2:83-95. 